Rolls-Royce, of course, is sitting pretty whatever happens; 168 Lockheed airbuses have been ordered so far, a record start for any commercial airliner, and Rolls-Royce will be supplying at least three engines worth $\$ 2.5$ million each for every one. Air Holdings, on the other hand, will, by 1973 , be getting one airbus a month and so far it has not sold any. When it comes to selling, Air Holdings is, of course, entirely dependent on the technical backing of Rolls-Royce and Lockheed engineers, but, faced with the prospect of holding thirty aircraft worth some $\$ 600$ million and no government aid, it is remarkably cheerful. It has been agreed that all the initial sales of the 1011 in the rest of the world, apart from the United States and countries to which the United States would refuse to sell the aircraft for political reasons, will be made by Air Holdings. With the European airbus not even off the council tables, let alone the drawing board and the ground-on Friday there is to be yet another crucial ministerial meetingthe 1011 has two competitors. One is the DC 10 , ordered by United and American airlines in the United States and powered by a General Electric engine which is a commercial adaptation of the engine developed for the C5A military transport. The other is the Boeing 747. The four-engined Boeing is, strictly speaking, a long haul aircraft capable of carrying five hundred people and the smaller and shorter ranged Lockheed should be better suited for the European routes. It should also be at an advantage over its direct competitor, the $\mathrm{DC} 10$. It is no secret that all the American domestic airlines would have preferred to have aircraft powered by the Rolls-Royce engine. In the world market, free from buy-American lobbies, that should prove to be Air Holdings' best selling point.

\section{Imperial Demise}

THE prospect of beer by the litre for British drinkers came a step closer last week. Mr Anthony Wedgwood Benn, the Minister of Technology, announced that the United Kingdom is to adopt the metric system of measurement by 1975-the target date already accepted by British industry for its timetable. The minister has accepted all the recommendations of the Standing Joint Committee on Metrication, which published a long-awaited report on July 26 . The report says that a Metrication Board should be set up to organize the change, which should begin in 1971. Although these recommendations were widely anticipated (it was the Confederation of British Industry which first came forward with the suggestion for the Metrication Board), the Government's decision is nevertheless welcome. The industrial change is going ahead fast--two weeks ago the British Standards Institution published the final programme for the engineering industry-but the non-industrial sector of the economy and the general public have been lagging behind. The establishment of the Metrication Board will at least provide a chance for publicity, even if the coordinating function of the board remains somewhat nebulous.

The report makes it clear that there is not much time to waste. It is "imperative" for the planning of the change in the general sectors of the economy to be put in hand; if this is not done, "the dynamism of the industrial change will be lost". In order to have enabling legislation on the statute book by January 1, 1971, a Bill will have to be introduced in the Parlia- mentary session 1969-70. The programme will allow for a good deal of flexibility - some sectors will finish before 1975, some after. In the schools, the emphasis should shift from imperial to metric units by 1969 , although major imperial units will continue to be taught for a few years after that.

The report dodges the difficult problem of producing a balance sheet for the change. "Both the benefits and costs of metrication are virtually impossible to quantify even for a single industrial concern." Nevertheless, the Government has asked the Metrication Board, when it is set up, to produce a sector by sector appreciation of the problems, including the costs involved. The cost-effectiveness of metrication is not therefore likely to be known until it is a fact. So far, certainly, hunch has played a greater part than has a sober analysis of the situation.

Reaction so far to the minister's announcement has been muted. Only one organization, the Business Equipment Trade Association-faced with greater costs than others-has made disapproving noises. The public still seems hardly aware of the revolution that is to overtake it-decimal coins by 1971, metric units by 1975 . This is clearly an unsatisfactory state of affairs, and the Metrication Board would do well to try to encourage discussion of the change, if only to condition the public. The report does open the door, if only a fraction, to those who feel the change is an intolerable burden. It says that the Metrication Board should be responsible for making recommendations to the Government on special cases of hardship which might merit consideration for compensation. Mr Benn seems not to accept this argument; his statement said "There can be no question of compensation; the costs of adopting metric weights and measures must lie where they fall." But if the board does start to consider compensation, the number of protesters is likely to increase as if by magic.

\section{Up in the Air}

SINCE the British order for F111 aircraft was cancelled, and Anglo-French collaboration on the variable geometry aircraft broke down, the Royal Air Force has been without an advanced combat aircraft suitable for the middle and late seventies. For some months, however, discussions have been in progress between the British Government and the Governments of Belgium, Canada, West Germany, Italy and the Netherlands. These came to a head two weeks ago in Bonn, when four of the governments signed an agreed memorandum which takes them one step further towards the building of a joint strike-reconnaissance aircraft for the seventies. Although Belgium and Canada have not so far signed the memorandum, it is thought possible that they may join in later, as the project definition stage advances.

It is easy to make fun of international projects like these, with their continual horse-trading over design leadership and their apparent inability to move beyond paperwork. But there are some reasons to believe that this project may have better fortune than its predecessors. Certainly it is becoming increasingly urgent for Britain and some of the other countries involved to find a successor to their existing aircraft. All the air forces involved, except Britain's, fly the United States F104 Starfighter aircraft, which has had 
mixed success operationally. The German air force seems to have had a particularly unhappy time with it. Unless this new project comes off, few of the aircraft industries involved in the six countries can have a very good chance of survival. West Germany's industry is perhaps the weakest of all, but despite this there were reports last week that the West German Government was keen to gain design leadership of the project.

Britain's bargaining position in the talks, which are likely to last about six months, will probably be based on two arguments. On the one hand, it is likely to bc argued that alone among the six, Britain has the capacity, though not perhaps the inclination, to go it alone. On the other hand, Britain is likely to point to groundwork already carried out by the British Aircraft Corporation, which has been putting together design details for a variable-geometry aircraft. (It is not in fact clear yet whether the British Government is basing discussions exclusively on this design, or would be willing to consider something else.) And although Britain's withdrawal from the Far East may make it easier to bring British requirements into line with those of Europe, there are still likely to be differences of opinion over specifications. The estimates of possible sales of 1,000 aircraft, worth $£ 2,000$ million, are therefore premature.

Collaboration on this scale always increases costs. According to $\mathrm{Mr}$ Healey, the British Minister of Defence, a two way collaboration increases costs by about 20 per cent. A six-way collaboration would doubtless be very much worse but, even so, if it is assumed that research and development costs are divided equally, the cost to each country of developing the aircraft collaboratively would be about a quarter of the cost of going it alone. This is a compelling inducement for the negotiators to reach reasonable terms.

\section{No Prisons for Zanzibar}

WESTERN penologists may envy the freedom of other countries to conduct experiments in penal reform. Zanzibar is to abolish courts of law and prison sentences for all crimes other than murder and robbery with violence. The governing council of the island hopes to eliminate prisons altogether, and in future offenders will be sent to penal reform institutions for five years where they will be taught a trade.

The Tanzanian High Commission in London has not yet received details of these reforms, so it is hard to assess their significance. It is not known what rights of defence will be accorded to those accused of crimes. And though it may be a fine ideal to abolish prisons, "penal reform institutions" could be different only in name.

Announcing the reforms on July 14 the President of Zanzibar said that poverty was the principal determinant of crime and that the government would concentrate on raising the standard of living. Although poverty is undoubtedly related to crime, it seems to be relative rather than absolute indigence that encourages antisocial activity. The Zanzibaris may be naive in supposing that increased wealth will diminish crime, or that offenders will be reformed by the acquisition of an honest trade. But there is much to be gained from experimenting with the conventional penal system; prisons are expensive, degrading and lamentably inefficient in performing their stated aims. The Home Office is unable to supply recent figures but more than half the British prison population of 1961 had been in prison before. Britain now spends some $£ 30$ million a year on the prison service; an average weekly cost of $£ 14$ per prisoner. If more than half the people who have received this expensive treatment can be expected to commit further crimes on their release, it is hard to be satisfied that prison either benefits the prisoner or protects society.

Since 1948 it has been judicial policy in Britain to send increasingly fewer categories of offender to prison. The Zanzibaris have apparently taken this policy to its logical conclusion. The results of their experiment, if it has been properly set up, will be watched with interest.

\section{Weeds Underwater}

MACHINERY, chemicals and biological control are being used on an increasingly large scale to clear weeds from British lakes, streams and ditches-a job traditionally carried out by unskilled labourers. In a recent bulletin, Mr T. O. Robson of the Agricultural Research Council's Weed Research Organization at Oxford describes the basic principles of weed control and summarizes new methods which have either already been shown to be successful, or which are still at the experimental stage (The Control of Aquatic Weeds, H.MSO, 5s. 9d.).

Although aquatic weeds may cause flooding and silting and also interfere with recreational activities such as fishing, boating and bathing, they also aerate water, provide shelter for smaller animals, consolidate the beds and banks of streams, provide food for other organisms and serve to fertilize deposits wherever plant detritus accumulates. For these reasons, $\mathrm{Mr}$ Robson maintains that total eradication of water weeds is seldom desirable, and that partial control by removal of some plants but not others, or temporary suppression of all plant growth at certain periods of the year, are usually more acceptable.

Most methods have drawbacks and, as Mr Robson points out, the possible adverse effects of, for example, herbicides on humans, fish and farm animals must always be carefully considered. Physical removal of weeds is probably the commonest method of control, and for this purpose boats fitted with either $V$-shaped cutters or reciprocating cutter-bars are used. A mowing machine has been introduced from the United States but has not been used to any great extent in Britain so far. Raking or "clotting" is a slow and expensive task and one which Mr Robson maintains is used only as a last resort. Dredging is also unsatisfactory because it does not eliminate the roots and underground parts of weeds, so that plants rapidly re-establish themselves. Experience of burning weeds on the banks of watercourses is limited, but Mr Robson points out that in some situations it may be possible to burn plants killed by herbicides.

Although biological control would seem to be a desirable method of controlling water weeds, it has not been used very widely. As indicated in the bulletin, however, the Ministry of Agriculture, Fisheries and Food recently began an investigation into the possible value of a fish-the Chinese grass carp-in this connexion. 